\title{
A novel approach reveals high zooplankton standing stock deep in the sea
}

\author{
Alexander Vereshchaka ${ }^{1}$, Galina Abyzova ${ }^{1}$, Anastasia Lunina ${ }^{1}$, Eteri Musaeva ${ }^{1}$, and Tracey Sutton ${ }^{2}$ \\ ${ }^{1}$ Institute of Oceanology, Russian Academy of Sciences, Nakhimov Pr. 36, Moscow, 117997 Russia \\ ${ }^{2}$ Halmos College of Natural Sciences and Oceanography, Nova Southeastern University, Dania Beach, FL 33004, USA \\ Correspondence to: Alexander Vereshchaka (alv@ocean.ru)
}

Received: 17 April 2016 - Published in Biogeosciences Discuss.: 25 April 2016

Revised: 16 September 2016 - Accepted: 26 September 2016 - Published: 21 November 2016

\begin{abstract}
In a changing ocean there is a critical need to understand global biogeochemical cycling, particularly regarding carbon. We have made strides in understanding upper ocean dynamics, but the deep ocean interior $(>1000 \mathrm{~m})$ is still largely unknown, despite representing the overwhelming majority of Earth's biosphere. Here we present a method for estimating deep-pelagic zooplankton biomass on an oceanbasin scale. We have made several new discoveries about the Atlantic, which likely apply to the world ocean. First, multivariate analysis showed that depth and Chl were the basic factors affecting the wet biomass of the main plankton groups. Wet biomass of all major groups was significantly correlated with Chl. Second, zooplankton biomass in the upper bathypelagic domain is higher than expected. Third, the majority of this biomass comprises macroplanktonic shrimps, which have been historically underestimated. These findings, coupled with recent findings of increased global deep-pelagic fish biomass, suggest that the contribution of the deep-ocean pelagic fauna for biogeochemical cycles may be more important than previously thought.
\end{abstract}

\section{Introduction}

The deep sea accounts for nearly $99 \%$ of the habitable volume of the planet (Dawson, 2012). Waters below $200 \mathrm{~m}$ are highly heterogeneous in space and time, harboring diverse biological resources which are not yet quantitatively estimated. These ecosystems are and will continue to be impacted by climate change due to the cumulative effect of different stressors on their biota, including expanding oxygen minimum zones, shoaling of aragonite saturation horizons, acidifica- tion, and warming (Okey et al., 2012). It is urgent that we estimate the biomass of the deep-sea biota for inventory purposes and for monitoring its changes in the future.

Studies on the deep-sea plankton biomass at selected sites include those in the North Pacific (e.g., Vinogradov, 1968; Murano et al., 1976; Yamaguchi et al., 2002a, b; Yamaguchi, 2004), eastern tropical Pacific (Sameoto, 1986), North Atlantic (Koppelmann and Weikert, 1992, 1999; Gislason, 2003; Vinogradov, 2005), Mediterranean Sea (Scotto di Carlo et al., 1984; Weikert and Trinkaus, 1990), Indian Ocean (Vinogradov, 1968), and Arabian Sea (Koppelmann and Weikert, 1997; Böttger-Schnack, 1996). Fewer results concern deep-sea zooplankton distribution over larger areas (Longhurst and Williams, 1979; Gaard et al., 2008). The data regarding quantitative distribution of the deep-sea zooplankton for the equatorial Atlantic and the South Atlantic Gyre are lacking. In addition to geographic restrictions, most deep-sea research has been concentrated on specific taxonomic groups (e.g., crustacean zooplankton; Burghart et al., 2007; Gaard et al., 2008), functional groups (e.g., gelatinous zooplankton; Lindsay and Hunt, 2005), or selected vertical zones (e.g., mesopelagic; Robison et al., 2010). Attempts to assess an entire deep-sea community have been rare and local (Vinogradov et al., 1996; Vereshchaka and Vinogradov, 1999; Vinogradov et al., 2000). Comparative assessments of entire water column plankton over large areas are absent.

Thus, it is timely to provide estimates of the zooplankton biomass throughout the water column over large areas. As any field data of the deep-sea zooplankton are inevitably local, we should find an indicator that is correlated with elements of the deep-sea zooplankton and that can be assessed over large water areas/volumes. Here we offer and test a 


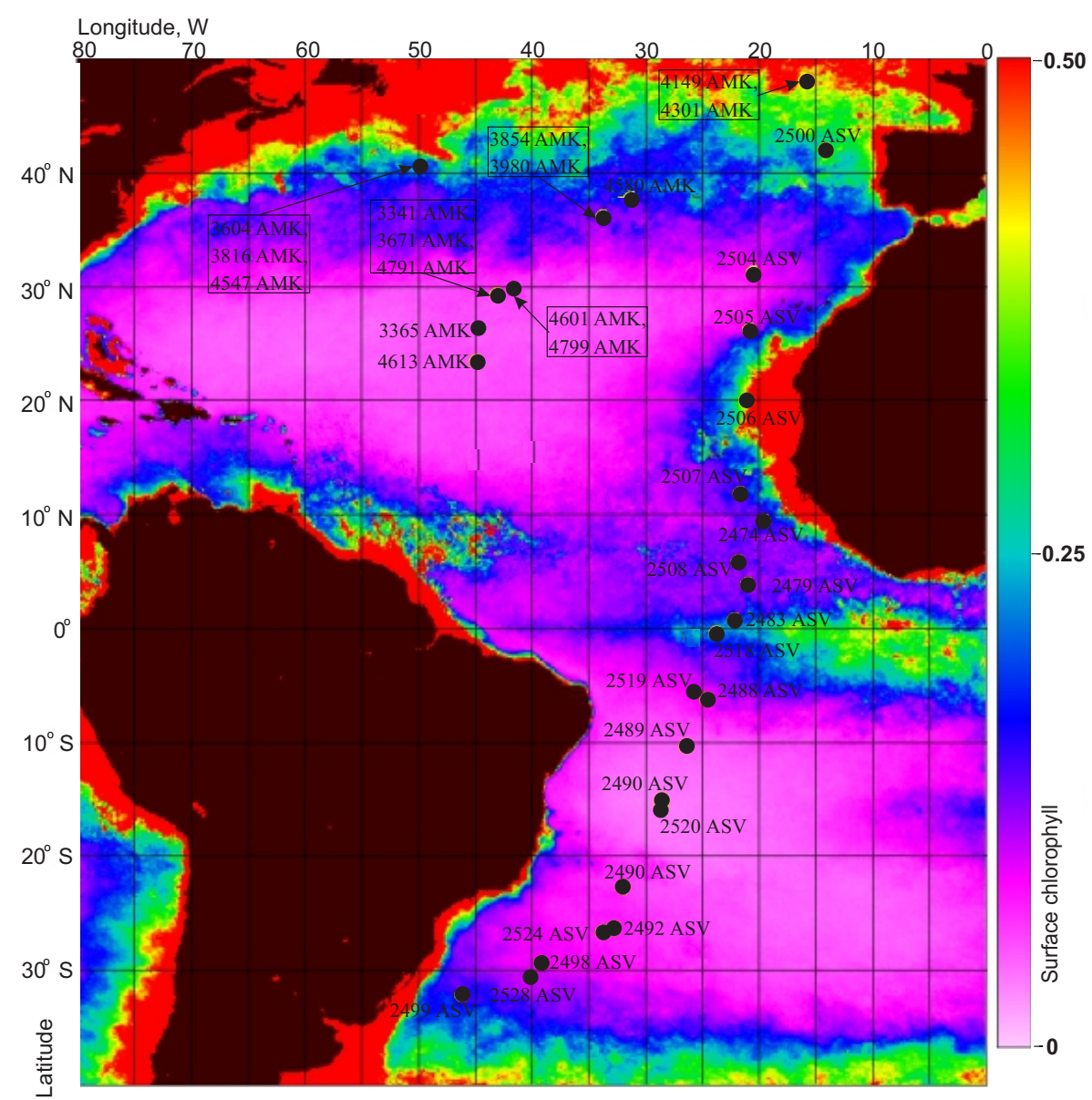

Figure 1. Deep-sea plankton stations (black circles) sampled during the cruises of R/V Akademik Sergey Vavilov (ASV) and R/V Akademik Mstislav Keldysh (AMK) (see also Table 1). Background: surface chlorophyll $a$ concentration averaged over 2013; scale is given (mg $\mathrm{m}^{-2}$ ) on the right.

hypothesis that the zooplankton wet biomass in the deeppelagic is correlated with surface chlorophyll concentration. This hypothesis has been corroborated for the epipelagic $(0-$ $200 \mathrm{~m}$ ) layer, where correlations have been obtained (Vinogradov et al., 1999). It remains completely unknown, however, if this dependence is valid for the deep sea below $200 \mathrm{~m}$. In theory, the standing stock of zooplankton should remain correlated with surface productivity and the correlation should decrease with depth. No large-scale data, however, are available on this subject. Here we attempt to fill that void by examining the relationship between remotely sensed sea surface data and in situ, discrete depth sampling data across the majority of the Atlantic Ocean (Fig. 1). In order to start this process, we will focus on the deep-sea mesoand macroplankton (1-10 cm length). This size fraction links primary and higher levels of oceanic production and is representatively sampled by the largest spectrum of plankton nets. As an indicator of surface productivity, surface chlorophyll concentration (Chl hereafter) derived from satellite information has been chosen as our indicator metric. We will check the presence of correlation for major groups of the zooplankton and for the different depth zones: epipelagic, main thermocline, and upper- and lower-bathypelagic zones. If correlations exist, we will assess the standing stock of the plankton over vertical zones and over geographical areas. Where possible, we will estimate the role of major plankton groups and different depth zones in the total standing stock of the zooplankton. If successful, this attempt will provide a new expedient method for evaluation of deep-sea resources.

\section{Methods}

Zooplankton distribution is strongly affected by the presence of land (islands, continents, seamounts) and the seafloor (Vereshchaka, 1995). The effect is prominent at a distance of tens of kilometers in the horizontal direction (Vereshchaka, 1990a, b, 1994; Melo et al., 2014) and hundreds of meters in the vertical direction (Vereshchaka; 1995; Vereshchaka and Vinogradov, 1999; Cartes et al., 2010). In order to minimize the land and the seafloor effects, this survey of the pelagic 
zooplankton in the open ocean will be made as far as possible from the bottom in the vertical direction and from the land in the horizontal direction.

Field data were taken in the deep central, South, and North Atlantic between 1996 and 2012 from ultraoligotrophic to mesotrophic areas roughly between $40^{\circ} \mathrm{S}$ and $40^{\circ} \mathrm{N}$ during the 36th and 37th cruises of the R/V Akademik Sergey Vavilov (ASV) and the 34th, 37th, 39th, 42nd, 46th, 47th, 49th, and 50th cruises of the R/V Akademik Mstislav Keldysh (AMK Table 1, Fig. 1). These areas include the two main Atlantic gyres (North and the South) and the equatorial Atlantic between them.

The whole database of this work contains two different datasets: (1) data of 2012-2013 (R/V Akademik Sergey Vavilov, mainly central and South Atlantic) and (2) data of 19942005 (R/V Akademik Mstislav Keldysh, mainly North Atlantic). Samples have been taken following the same protocol, but identification was much more precise for the first dataset. The community composition, diversity, and other community patterns have been analyzed in detail for the first dataset and presented in a recent paper (Vereshchaka et al., 2016). The second dataset contains representative biomass values and significantly contributes to the metadata concerning deep zooplankton; here we combine both datasets for a more comprehensive analysis. We excluded data from temperate waters where the major spring peaks in primary production are being exported from the euphotic zone (0-200 $\mathrm{m}$ depth) and reaching abyssal depths $(4000 \mathrm{~m})$ with a significant time lag (e.g., 42 days: Smith et al., 2002); this lag differs for different depth zones that may corrupt possible correlations.

Samples were taken between $1 \mathrm{~h}$ after sunset and $1 \mathrm{~h}$ before sunrise in order to make a unified nighttime picture of the vertical distribution of animals. This method was adopted to avoid the confounding effects of diel vertical migration. We sampled four discrete depth strata: (1) the epipelagic zone (0-200 m); (2) the main thermocline (from $200 \mathrm{~m}$ to the depth of the $7{ }^{\circ} \mathrm{C}$ isotherm, within $550-800 \mathrm{~m}$ ); (3) the zone from the lower boundary of the main thermocline to $1500 \mathrm{~m}$, mainly Antarctic Transitional Waters, which we define here as the upper bathypelagic; and (4) the layer $1500-3000 \mathrm{~m}$, mainly North Atlantic Deep Waters, which we define here as the lower bathypelagic (Fig. 2). The upper boundary of the bathypelagic zone as defined here did not coincide with the traditional one $(1000 \mathrm{~m})$, because our sampling was associated with water masses. The lower boundary of the bathypelagic was $3000 \mathrm{~m}$ instead of the usually adopted $4000 \mathrm{~m}$, as we had to avoid sampling of the benthopelagic zone.

We used a closing Bogorov-Rass (BR) plankton net $\left(1 \mathrm{~m}^{2}\right.$ opening, $500 \mu \mathrm{m}$ mesh size, towed at a speed of $1 \mathrm{~m} \mathrm{~s}^{-1}$ ), which was proven to successfully sample deep-sea plankton of the size range of 1-50 mm long (Vinogradov et al., 1996, 2000); smaller animals may pass through the sieve during filtration. The net was deployed at the maximal depth of haul, then opened and towed vertically upwards, and finally closed at the minimal depth of haul with a mechanical device. The minimal horizontal distance between station and the land was $400 \mathrm{~km}$ and the minimal vertical distance the lower boundary of the deepest haul and the seafloor was $750 \mathrm{~m}$ (Table 1), so that the land/seafloor effect could be ignored.

We divided the net plankton into four major groups: non-gelatinous mesozooplankton (dominated by copepods and chaetognaths; $1-30 \mathrm{~mm}$ length), gelatinous mesozooplankton (mainly siphonophorans and medusae; individual or zooid; 1-30 mm length), decapods, and small (macroplanktonic) fishes (both groups over $30 \mathrm{~mm}$ length). Identification was done according to the literature (e.g., Rose, 1933; Brodsky, 1950; Mauchline and Fisher, 1969; Brodsky et al., 1983; Markhasheva, 1996). Synonymy of species was corrected according to www.marinespecies.org. Decapods, fishes, and gelatinous species were weighed with a precision of $0.1 \mathrm{~g}$ before fixation. Wet weight of mesoplanktonic groups was estimated according to adopted procedures (Vinogradov et al., 1996, 2000; Gaard et al., 2008). In brief, wet weight $w_{\text {tot }}$ of the non-gelatinous mesozooplankton (mainly copepods) was estimated as $w_{\text {tot }}=\Sigma\left(k \times l_{i}^{3}\right)$, where $l_{i}$ is length of an individual specimen (measured with an ocular ruler) and $k$ is a species-dependent coefficient; tables of these coefficients have been published elsewhere (e.g., Vinogradov and Shushkina, 1987).

Surface chlorophyll $a$ concentration (Chl) derived from satellite images was used as a measure of the surface productivity. Chl data were taken from Aqua MODIS (level 3, $4 \mathrm{~km}$ resolution) from 2003 to 2015. Before this period Chl data were taken from SeaWiFS (level 3,9 km resolution) from 1997 to 2002. Chl data were averaged over 1 year preceding the sampling date and over a $5^{\circ} \times 5^{\circ}$ square (with the sampling site in the center).

In order to establish relationships between the major plankton group wet biomass and possible environmental factors, canonical correspondence analysis (CCA: Ter Braak, 1986) was performed on major group biomass using an assortment of environmental variables: temporal (month and year), spatial (latitude, longitude, and depth), and surface chlorophyll concentration (Chl). As the sampling was associated with distinct water masses, such environmental parameters as temperature, salinity, and depth were correlated and only one of them, the depth, was included in CCAs. CCA is a powerful multivariate technique to extract synthetic environmental gradients from ecological data (Ter Braak and Verdonschot, 1995). Ordination axes are based on the measured environmental variables and represent linear combinations of the variables. Arrows showing variables in the ordination plots are proportional in length to the importance of each variable (Ter Braak, 1986), and therefore community variation can be directly related to environmental variation. CCAs included either all hauls or hauls from separate strata and made it possible to assess the contribution of all analyzed factors. 
Table 1. List of stations and cruises of R/V Akademik Sergey Vavilov (ASV) and R/V Akademik Mstislav Keldysh (AMK). Sampling zones: E - epipelagic; M - main thermocline; U - upper bathypelagic; L - lower bathypelagic; $\mathrm{T}$ - total haul (0-3000 m; net was not closed).

\begin{tabular}{|c|c|c|c|c|c|c|c|}
\hline $\begin{array}{l}\text { Station } \\
\text { Designation }\end{array}$ & Date & Latitude & Longitude & $\begin{array}{l}\text { Sampling } \\
\text { zones }\end{array}$ & $\begin{array}{r}\text { Surface } \\
\text { chlorophyll } a \\
\text { concentration } \\
\left(\mathrm{mg} \mathrm{m}^{-2}\right)\end{array}$ & $\begin{array}{r}\text { Surface } \\
\text { temperature, } \\
{ }^{\circ} \mathrm{C}\end{array}$ & Depth, m \\
\hline 2474 ASV & 24.10 .2012 & $9^{\circ} 25^{\prime} \mathrm{N}$ & $19^{\circ} 44^{\prime} \mathrm{W}$ & EMUL & 0.12 & 28.5 & 4282 \\
\hline 2479 ASV & 25.10 .2012 & $3^{\circ} 51^{\prime} \mathrm{N}$ & $21^{\circ} 15^{\prime} \mathrm{W}$ & EMUL & 0.13 & 27.2 & 5235 \\
\hline $2483 \mathrm{ASV}$ & 28.10 .2012 & $0^{\circ} 50^{\prime} \mathrm{N}$ & $22^{\circ} 26^{\prime} \mathrm{W}$ & EMUL & 0.17 & 26.4 & 4360 \\
\hline 2488 ASV & 29.10 .2012 & $6^{\circ} 12^{\prime} \mathrm{S}$ & $24^{\circ} 05^{\prime} \mathrm{W}$ & EMU & 0.09 & 25.1 & 3800 \\
\hline 2489 ASV & 30.10 .2012 & $10^{\circ} 18^{\prime} \mathrm{S}$ & $26^{\circ} 37^{\prime} \mathrm{W}$ & EMUL & 0.05 & 24.4 & 5500 \\
\hline $2490 \mathrm{ASV}$ & 01.11 .2012 & $15^{\circ} 06^{\prime} \mathrm{S}$ & $28^{\circ} 45^{\prime} \mathrm{W}$ & EMUL & 0.03 & 24.6 & 5030 \\
\hline $2491 \mathrm{ASV}$ & 03.11 .2012 & $22^{\circ} 43^{\prime} \mathrm{S}$ & $32^{\circ} 05^{\prime} \mathrm{W}$ & EMUL & 0.07 & 23.5 & 4690 \\
\hline $2492 \mathrm{ASV}$ & 05.11 .2012 & $26^{\circ} 39^{\prime} \mathrm{S}$ & $33^{\circ} 58^{\prime} \mathrm{W}$ & EMUL & 0.07 & 22.2 & 4710 \\
\hline 2498 ASV & 07.11 .2012 & $29^{\circ} 27^{\prime} \mathrm{S}$ & $39^{\circ} 15^{\prime} \mathrm{W}$ & EMUL & 0.09 & 20.5 & 4724 \\
\hline 2499 ASV & 10.11.2012 & $32^{\circ} 11^{\prime} \mathrm{S}$ & $46^{\circ} 26^{\prime} \mathrm{W}$ & $\mathrm{T}$ & 0.10 & 19.6 & 3780 \\
\hline $2500 \mathrm{ASV}$ & 23.09.2013 & $41^{\circ} 58^{\prime} \mathrm{N}$ & $14^{\circ} 17^{\prime} \mathrm{W}$ & EMUL & 0.29 & 19.3 & 5000 \\
\hline $2504 \mathrm{ASV}$ & 27.09.2013 & $31^{\circ} 12^{\prime} \mathrm{N}$ & $20^{\circ} 48^{\prime} \mathrm{W}$ & EMU & 0.09 & 23.1 & 3150 \\
\hline $2505 \mathrm{ASV}$ & 29.09.2013 & $26^{\circ} 14^{\prime} \mathrm{N}$ & $21^{\circ} 03^{\prime} \mathrm{W}$ & EMUL & 0.12 & 24.3 & 4700 \\
\hline $2506 \mathrm{ASV}$ & 30.09 .2013 & $19^{\circ} 59^{\prime} \mathrm{N}$ & $21^{\circ} 22^{\prime} \mathrm{W}$ & EMUL & 0.46 & 25.3 & 3780 \\
\hline $2507 \mathrm{ASV}$ & 03.10 .2013 & $11^{\circ} 50^{\prime} \mathrm{N}$ & $21^{\circ} 47^{\prime} \mathrm{W}$ & EMUL & 0.17 & 28.0 & 4900 \\
\hline $2508 \mathrm{ASV}$ & 04.10 .2013 & $5^{\circ} 50^{\prime} \mathrm{N}$ & $22^{\circ} 00^{\prime} \mathrm{W}$ & EMUL & 0.12 & 27.2 & 3800 \\
\hline $2518 \mathrm{ASV}$ & 10.10 .2013 & $1^{\circ} 25^{\prime} \mathrm{S}$ & $24^{\circ} 00^{\prime} \mathrm{W}$ & EMUL & 0.17 & 25.2 & 4700 \\
\hline 2519 ASV & 11.10 .2013 & $07^{\circ} 01^{\prime} \mathrm{S}$ & $26^{\circ} 04^{\prime} \mathrm{W}$ & EMUL & 0.16 & 25.1 & 4500 \\
\hline $2520 \mathrm{ASV}$ & 14.10 .2013 & $15^{\circ} 35^{\prime} \mathrm{S}$ & $28^{\circ} 41^{\prime} \mathrm{W}$ & EMUL & 0.03 & 24.7 & 5100 \\
\hline $2524 \mathrm{ASV}$ & 19.10 .2013 & $26^{\circ} 23^{\prime} \mathrm{S}$ & $32^{\circ} 53^{\prime} \mathrm{W}$ & EMU & 0.07 & 20.5 & 3000 \\
\hline $2528 \mathrm{ASV}$ & 21.10. 2013 & $31^{\circ} 00^{\prime} \mathrm{S}$ & $40^{\circ} 38^{\prime} \mathrm{W}$ & EMU & 0.09 & 18.4 & 2250 \\
\hline 3341 AMK & 12.09.1994 & $29^{\circ} 06^{\prime} \mathrm{N}$ & $43^{\circ} 12^{\prime} \mathrm{W}$ & EMUL & 0.06 & 26.4 & 3205 \\
\hline 3365 AMK & 16.09.1994 & $26^{\circ} 12^{\prime} \mathrm{N}$ & $44^{\circ} 54^{\prime} \mathrm{W}$ & EMUL & 0.05 & 26.7 & 3887 \\
\hline 3604 AMK & 08.09.1995 & $41^{\circ} 42^{\prime} \mathrm{N}$ & $49^{\circ} 54^{\prime} \mathrm{W}$ & EMUL & 0.44 & 20.6 & 3749 \\
\hline 3671 AMK & 28.08 .1996 & $29^{\circ} 06^{\prime} \mathrm{N}$ & $43^{\circ} 12^{\prime} \mathrm{W}$ & EMUL & 0.06 & 26.9 & 5270 \\
\hline 3816 AMK & 10.09.1998 & $41^{\circ} 42^{\prime} \mathrm{N}$ & $49^{\circ} 54^{\prime} \mathrm{W}$ & EMUL & 0.48 & 20.6 & 3750 \\
\hline 3854 AMK & 28.10 .1998 & $36^{\circ} 12^{\prime} \mathrm{N}$ & $33^{\circ} 54^{\prime} \mathrm{W}$ & EMU & 0.13 & 20.6 & 2470 \\
\hline 3980 AMK & 9-10.10.1999 & $36^{\circ} 12^{\prime} \mathrm{N}$ & $33^{\circ} 54^{\prime} \mathrm{W}$ & EMUL & 0.11 & 20.5 & 3285 \\
\hline 4149 AMK & $10-11.06 .2001$ & $48^{\circ} 06^{\prime} \mathrm{N}$ & $16^{\circ} 06^{\prime} \mathrm{W}$ & EMUL & 0.44 & 13.0 & 4700 \\
\hline $4301 \mathrm{AMK}$ & $1-4.06 .2002$ & $48^{\circ} 06^{\prime} \mathrm{N}$ & $16^{\circ} 06^{\prime} \mathrm{W}$ & EMUL & 0.55 & 12.7 & 4800 \\
\hline 4547 AMK & $25-26.06 .2003$ & $41^{\circ} 42^{\prime} \mathrm{N}$ & $49^{\circ} 54^{\prime} \mathrm{W}$ & EMUL & 0.40 & 8.8 & 3700 \\
\hline 4580 AMK & 30.07 .2003 & $37^{\circ} 54^{\prime} \mathrm{N}$ & $31^{\circ} 30^{\prime} \mathrm{W}$ & EMU & 0.15 & 23.9 & 2070 \\
\hline $4601 \mathrm{AMK}$ & 08.08 .2003 & $30^{\circ} 06^{\prime} \mathrm{N}$ & $42^{\circ} 06^{\prime} \mathrm{W}$ & EMU & 0.06 & 26.9 & 1800 \\
\hline 4613 AMK & $12-13.08 .2003$ & $23^{\circ} 24^{\prime} \mathrm{N}$ & $45^{\circ} 00^{\prime} \mathrm{W}$ & EMUL & 0.06 & 25.3 & 4700 \\
\hline 4791 AMK & $24-25.08 .2005$ & $29^{\circ} 06^{\prime} \mathrm{N}$ & $43^{\circ} 12^{\prime} \mathrm{W}$ & EMU & 0.06 & 26.4 & 3070 \\
\hline 4799 AMK & 28.08 .2005 & $30^{\circ} 06^{\prime} \mathrm{N}$ & $42^{\circ} 06^{\prime} \mathrm{W}$ & EMU & 0.06 & 26.3 & 2545 \\
\hline
\end{tabular}

Calculations, statistical procedures, regression analysis, and ANOVA tests were carried out with the use of Excel and STATISTICA, and CCAs were carried out with PAST 3.04 (Hammer et al., 2001).

\section{Results}

Over 300 taxa were identified, counted, measured, and their weight calculated to estimate standing stocks (the plankton assemblages are considered in detail elsewhere Vereshchaka et al., 2016). The main contribution to the total zooplankton standing stock was made by decapods, fol- lowed by non-gelatinous mesozooplankton, gelatinous mesozooplankton, and fishes (Table 2).

The epipelagic zone was dominated by the two groups of mesozooplankton, the main thermocline was dominated by non-gelatinous mesozooplankton and decapods, the upper bathypelagic zone was dominated by decapods, and the lower bathypelagic zone was dominated by gelatinous zooplankton (Table 2). The dominant role of decapods will be further quantified as a separate parameter, the share of decapods in the total plankton wet biomass (\%).

Actual vertical distribution of major groups varied, but typical profiles are represented for the northwest and north- 


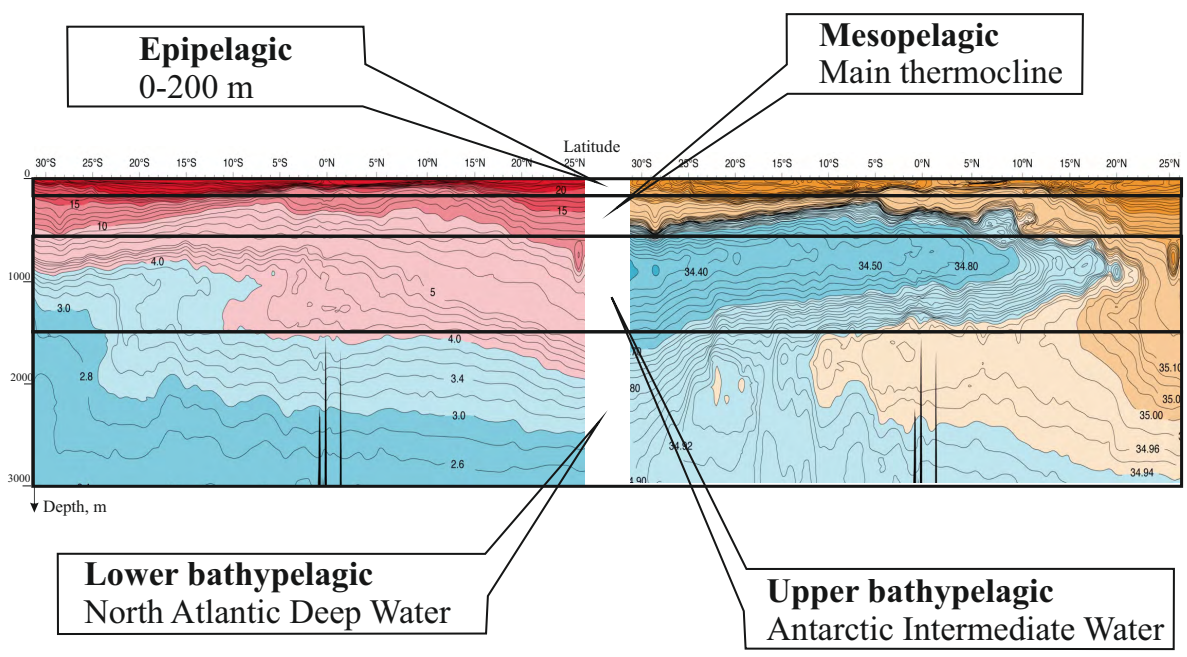

Figure 2. Temperature $\left({ }^{\circ} \mathrm{C}\right.$, left) and salinity (\%o, right) along transect A16 (Koltermann et al., 2011).

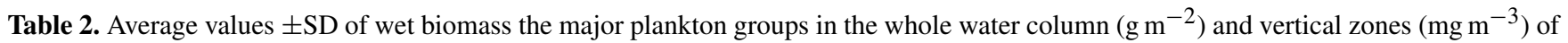
the Atlantic Ocean.

\begin{tabular}{lrrrrr}
\hline Vertical zones & $\begin{array}{r}\text { Non-gelatinous } \\
\text { mesoplankton }\end{array}$ & $\begin{array}{r}\text { Gelatinous } \\
\text { mesoplankton }\end{array}$ & Decapods & $\begin{array}{r}\text { Fishes } \\
\text { Total plankton }\end{array}$ & $\begin{array}{r}\text { Number of } \\
\text { samples }\end{array}$ \\
\hline Whole water column $(0-3000 \mathrm{~m})$ & $13.38 \pm 24.08$ & $8.07 \pm 17.33$ & $15.63 \pm 31.04$ & $1.25 \pm 2.32$ & $37.08 \pm 58.49$ \\
Epipelagic zone & $28.32 \pm 54.86$ & $20.16 \pm 53.96$ & $0.58 \pm 2.16$ & $0.62 \pm 0.86$ & $49.07 \pm 78.19$ \\
Main thermocline zone & $5.68 \pm 12.34$ & $1.86 \pm 4.03$ & $5.40 \pm 9.26$ & $0.38 \pm 0.63$ & $12.93 \pm 18.53$ \\
Upper bathypelagic zone & $4.30 \pm 9.20$ & $4.12 \pm 11.14$ & $12.07 \pm 25.73$ & $0.61 \pm 0.81$ & $20.49 \pm 36.28$ \\
Lower bathypelagic zone & $0.19 \pm 0.16$ & $1.79 \pm 4.40$ & $0.04 \pm 0.16$ & $0.04 \pm 0.16$ & $2.02 \pm 9.71$ \\
\hline
\end{tabular}

east corners of studied area (Fig. 3a, b), for the central part and the eastern periphery of the North Atlantic Gyre (Fig. 3c, d), and for the equatorial area and southwestern periphery of the South Atlantic Gyre (Fig. 3 EF).

Multivariate CCA with all hauls included (Fig. 4a) showed aggregation of hauls in two groups. The first group (the left of OY axis) was mainly represented by the epi- and lower bathypelagic hauls and related to non-gelatinous, gelatinous, and total plankton. The second group (the right of OY axis) was represented by the and upper/lower bathypelagic hauls and related to the share of decapods. The first factor (F1) was mainly linked to depth, and the second factor (F2) was primarily associated with Chl (Fig. 4a). The contribution of other factors was less significant. Such variables as Chl and depth had the largest effect on wet biomass of all major groups, while the share of decapods was mostly linked to depth.

Multivariate CCA with only epipelagic hauls (Fig. 4b) showed one group of samples. The first factor (F1) was mainly linked to Chl, and the second factor (F2) was primarily associated with month (Fig. 4b). Chl had the largest effect on biomass of both mesoplanktonic groups and total plankton, while decapods and fish were also linked to month.
Multivariate CCA with hauls from the main thermocline (Fig. 4c) showed aggregation of hauls in two groups: one was mainly related to fishes and the share of decapods (the left of OY axis), while another was linked to both groups of mesoplankton and total plankton (the right of OY axis). The first factor (F1) was mainly linked to year and latitude, and the second factor (F2) was primarily associated with longitude (Fig. 4c).

Multivariate CCA with upper bathypelagic hauls (Fig. 4d) showed aggregation of hauls in two groups: one was mainly related to the share of decapods (the left of OY axis), while another was linked to main plankton groups (the right of OY axis). The first factor (F1) was mainly linked to Chl, and the second factor (F2) was primarily associated with month and year (Fig. 4d).

Multivariate CCA with lower bathypelagic hauls (Fig. 4e) showed aggregation of hauls in two groups: one was mainly related to the share of decapods (the left of OY axis), while another was linked to plankton groups (the right of OY axis). The first factor (F1) was mainly linked to longitude and year, and the second factor (F2) was primarily associated with $\mathrm{Chl}$ (Fig. 4e).

Multivariate CCA with wet biomass values integrated over whole water column (Fig. 4f) showed aggregation of hauls in 


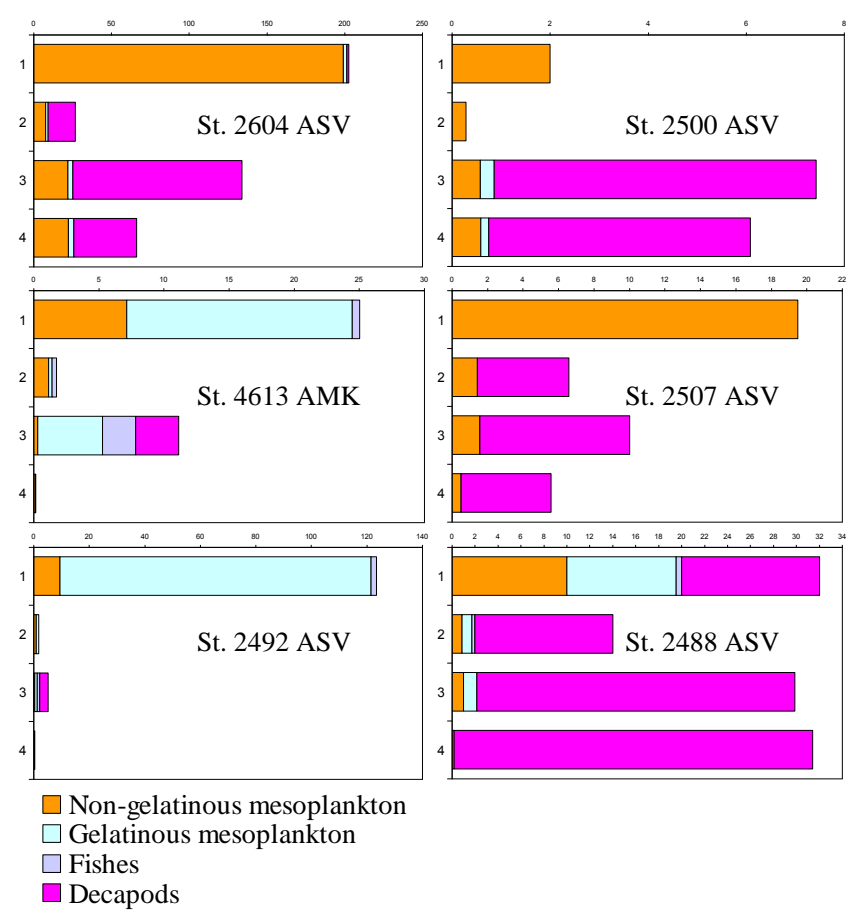

Figure 3. Wet biomass profiles $\left(\mathrm{mg} \mathrm{m}^{-3}\right)$ of the main plankton groups in the epipelagic zone (1), main thermocline (2), upper bathypelagic zone (3), and lower bathypelagic zone (4) obtained during the cruises of R/V Akademik Sergey Vavilov (ASV) and R/V Akademik Mstislav Keldysh (AMK) (see also Fig. 1 and Table 1).

two groups: one was mainly related to the share of decapods (the right of OY axis), while another was linked to plankton groups (the left of OY axis). The first factor (F1) was mainly linked to $\mathrm{Chl}$, month, and year, and the second factor (F2) was primarily associated with geographical coordinates (Fig. 4f).

Results of multivariate analyses allow a search for possible correlations between wet biomass of the major plankton groups and the most important environmental factor, $\mathrm{Chl}$. As chlorophyll and biomass data were not normally distributed, they were $\log$-log-transformed before fitting a linear regression. After transformation, all data sets except fish biomass in all strata and decapod biomass in the epipelagic have passed the Jarque-Bera (JB) test for normal distribution.

The total zooplankton wet biomass in the whole water column and the biomass of all major faunal groups were highly correlated with the averaged Chl (Fig. 5, Table 3). Moreover, in most cases the standing stock of the major groups in each of the vertical zones was also correlated with Chl; the dependence was more robust for upper vertical zones and weakened with depth.

Having the correlation between the total zooplankton standing stock and Chl, we calculated the total zooplankton standing stock (wet biomass under $1 \mathrm{~m}^{-2}$ in the whole water column) and standing stocks within each strata (wet biomass under $1 \mathrm{~m}^{-2}$ integrated over whole layer) over selected areas. We did that for three rectangular areas roughly corresponding to the North and South Atlantic gyres and the equatorial Atlantic (Fig. 6). The maximum plankton stock was found in the equatorial Atlantic $\left(3.8 \times 10^{7} \mathrm{t}\right.$ wet weight $)$, with the South and North Atlantic gyres being approximately half $\left(2.2 \times 10^{7} \mathrm{t}\right)$ and one-quarter $\left(1.0 \times 10^{7} \mathrm{t}\right)$ of this amount, respectively. Contribution of various vertical zones to the total plankton standing stock was similar in the three selected areas (Fig. 6). The contribution of the main thermocline zone was the smallest portion of the total plankton stock (13-16\%), the epipelagic and lower bathypelagic zones were intermediate (15-25\%), and the upper bathypelagic zone contributed the highest portion (41-48\%). In terms of faunal contributions, gelatinous and non-gelatinous mesozooplankton accounted for nearly one-quarter of the total zooplankton stock, while the decapods composed approximately half. Various species of the decapod genera Acanthephyra A. Milne-Edwards, 1881 and Gennadas Spence Bate, 1881 were dominant throughout the studied area, Notostomus A. Milne-Edwards, 1881 and Systellaspis Spence Bate, 1888 were dominant in the equatorial area and South Atlantic Gyre.

\section{Discussion}

Although scant on the global scale, our deep-sea samples collected during the last 20 years using standardized methods throughout the whole water column provide an unprecedented opportunity to investigate the distribution of zooplankton biomass at an ocean-basin scale. This is the first snapshot of the biomass distribution throughout the whole water column over a significant oceanic area. Further, this is a first attempt to quantitatively connect the dots related to surface productivity and deep-sea zooplankton biomass, including the bathypelagic zone, which contained the highest portion of water column meso/macrozooplankton standing stock.

The wet biomass profiles (Fig. 3), although different at various sites, show same decrease in the mesoplankton biomass, as has been known before (e.g., Vinogradov, 1970). As for novelty, high decapod biomasses are recorded from many sites. Since these animals may avoid plankton nets, high biomass values are even more striking.

Multivariate analysis showed that depth and Chl were the main general factors affecting the wet biomass of main plankton groups (Fig. 4a). Obtained regressions between $\mathrm{Chl}$ and biomass of the major plankton groups are obfuscated by several factors. First, algorithms for conversion of satellite images to Chl data are not perfect (Gregg and Rousseaux, 2014). Second, Chl data, even if estimated unerringly, do not reflect surface productivity thoroughly: autotrophic organisms may live far below the surface and even create deep maxima with significant chlorophyll concentration not de- 


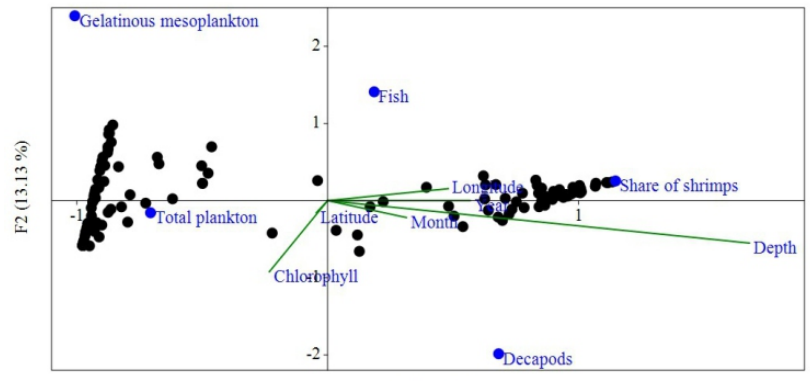

(a)

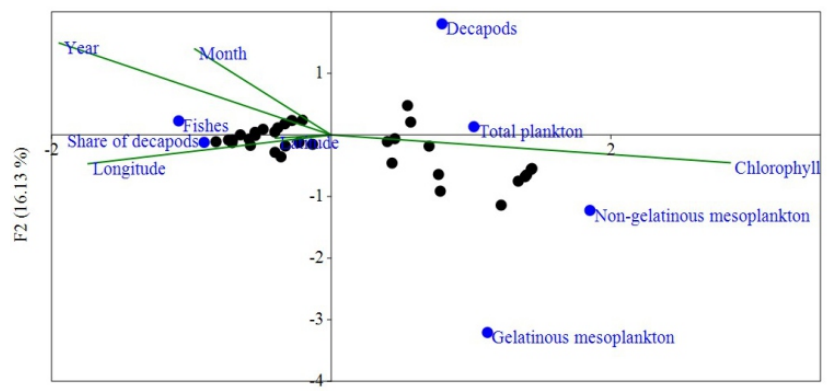

(c)

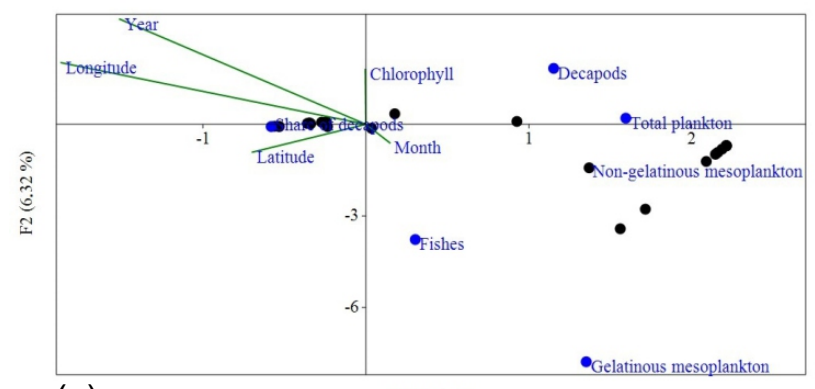

(e)

F1 (91.59\%)

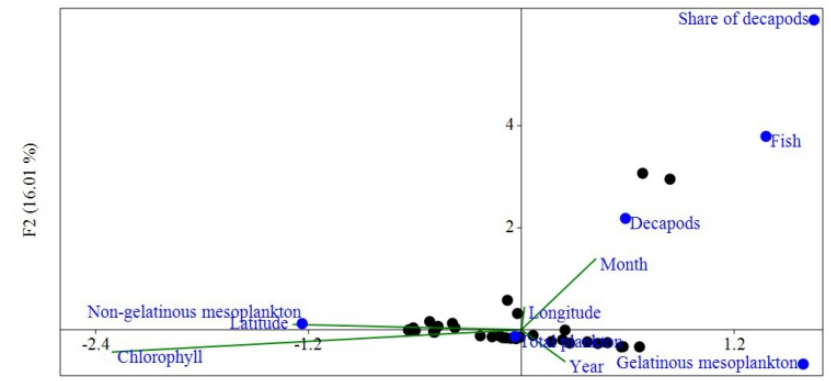

(b)
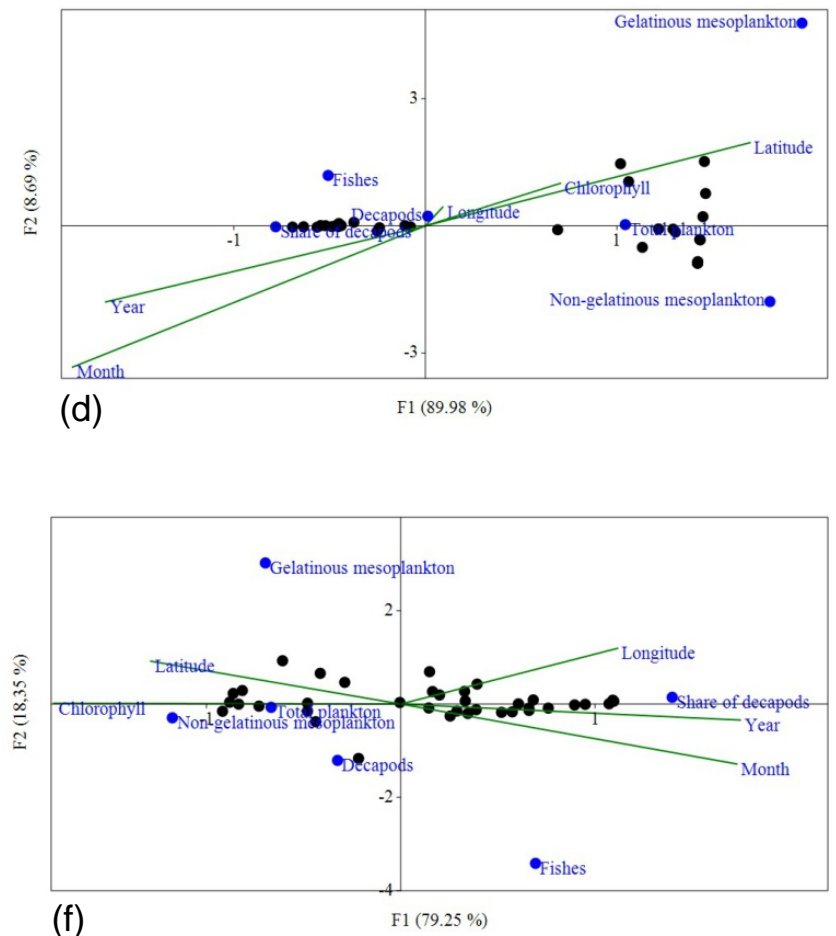

Figure 4. CCAs with all hauls included (a), with hauls taken in the epipelagic zone (b), in the main thermocline (c), in the upper (d) and in the lower (e) bathypelagic zones, and in the whole water column (f). The two first axes (F1 and F2) are shown with their respective explained variance.

tectable via satellites (Uitz et al., 2006). Third, the trophic structure of deep-pelagic communities and deep-water circulation locally differ, thus providing different conditions for downward energy transfer and accumulation of organic matter in the zooplankton wet biomass. It is all the more interesting that our data do show statistically significant correlation between $\mathrm{Chl}$ and the deep zooplankton biomass. The use of Chl averaged over a $5^{\circ} \times 5^{\circ}$ area and a 1 -year period provides a new and productive approach to assess the deep pelagic biomass. The use of different temporal and spatial scaling may improve this approach in the future.

Although our results provide a means for calculating global zooplankton wet biomass by integrating satellite remote sensing with in situ sampling, some caveats must be noticed, including the following:
- Correlations may be different outside the tropi$\mathrm{cal} /$ subtropical region of the Atlantic Ocean. Studies in the epipelagic zone show that such correlations are better in warm waters than in the cold waters (Vinogradov et al., 1999).

- Correlations may be different in different oceans. Our data show better correlation between the Chl concentration and the zooplankton wet biomass in the epipelagic zone than in Vinogradov et al. (1999): 0.67 vs. 0.53. We used field data from the Atlantic Ocean only, while Vinogradov et al. (1999) based their studies on a set of data from the Atlantic, Indian, and Pacific oceans. Each ocean probably requires an individual approach until 
Table 3. Correlations between $\log$-transformed values of surface chlorophyll $a$ concentration $\left(\mathrm{Chl}, \mathrm{mg} \mathrm{m}^{-2}\right)$ and wet biomass $\left(B\right.$, $\mathrm{g} \mathrm{m}^{-2}$ for the whole water column and $\mathrm{mg} \mathrm{m}^{-3}$ for vertical zones): coefficients of determination $\left(R^{-2}\right)$, equations, and levels of significance $\left(* * * *\right.$ indicate $p<0.001,{ }^{* * *}$ for $p<0.01,{ }^{* *}$ for $p<0.01,{ }^{*}$ for $\left.p<0.05\right)$.

\begin{tabular}{|c|c|c|c|c|c|c|c|c|}
\hline \multirow[t]{2}{*}{ Vertical zones } & \multicolumn{2}{|c|}{ Non-gelatinous mesoplankton } & \multicolumn{2}{|c|}{ Gelatinous mesoplankton } & \multicolumn{2}{|r|}{ Decapods } & \multicolumn{2}{|c|}{ Total plankton } \\
\hline & $R^{2}$ & $\begin{array}{l}\text { Regression } \\
\text { equations }\end{array}$ & $R^{2}$ & $\begin{array}{l}\text { Regression } \\
\text { equations }\end{array}$ & $R^{2}$ & $\begin{array}{l}\text { Regression } \\
\text { equations }\end{array}$ & $R^{2}$ & $\begin{array}{l}\text { Regression } \\
\text { equations }\end{array}$ \\
\hline $\begin{array}{l}\text { Whole water } \\
\text { column, } n=36\end{array}$ & $0.53^{* * * * *}$ & $B=1.14 \mathrm{Chl}+1.78$ & $0.18^{* * *}$ & $B=1.13 \mathrm{Chl}+1.20$ & $0.07^{*}$ & $B=0.90 \mathrm{Chl}+1.15$ & $0.54^{* * * *}$ & $B=1.19 \mathrm{Chl}+2.35$ \\
\hline $\begin{array}{l}\text { Epipelagic zone, } \\
n=35\end{array}$ & $0.50^{* * * *}$ & $B=1.16 \mathrm{Chl}+2.10$ & 0.00 & $B=0.04 \mathrm{Chl}+0.47$ & \multicolumn{2}{|c|}{ Test for normal distribution not passed } & $0.37^{* * * *}$ & $B=1.06 \mathrm{Chl}+2.29$ \\
\hline $\begin{array}{l}\text { Main } \\
\text { thermocline } \\
\text { zone, } n=35\end{array}$ & $0.48^{* * * * *}$ & $B=1.20 \mathrm{Chl}+1.35$ & $0.16^{*}$ & $B=1.13 \mathrm{Chl}+0.44$ & $0.07^{*}$ & $B=0.96 \mathrm{Chl}+0.46$ & $0.40^{* * * *}$ & $B=1.25 \mathrm{Chl}+1.86$ \\
\hline $\begin{array}{l}\text { Upper } \\
\text { bathypelagic } \\
\text { zone, } n=35\end{array}$ & $0.70^{* * * *}$ & $B=1.38 \mathrm{Chl}+1.44$ & $0.13^{*}$ & $B=1.15 \mathrm{Chl}+0.49$ & $0.13^{*}$ & $B=1.35 \mathrm{Chl}+1.18$ & $0.52^{* * * *}$ & $B=1.43 \mathrm{Chl}+2.15$ \\
\hline $\begin{array}{l}\text { Lower } \\
\text { bathypelagic } \\
\text { zone, } n=26\end{array}$ & $0.66^{* * * *}$ & $B=1.36 \mathrm{Chl}+0.87$ & $0.30 * *$ & $B=1.21 \mathrm{Chl}-0.09$ & $0.11^{*}$ & $B=1.12 \mathrm{Chl}+0.36$ & $0.46^{* * * *}$ & $B=0.48 \mathrm{Chl}+0.51$ \\
\hline
\end{tabular}

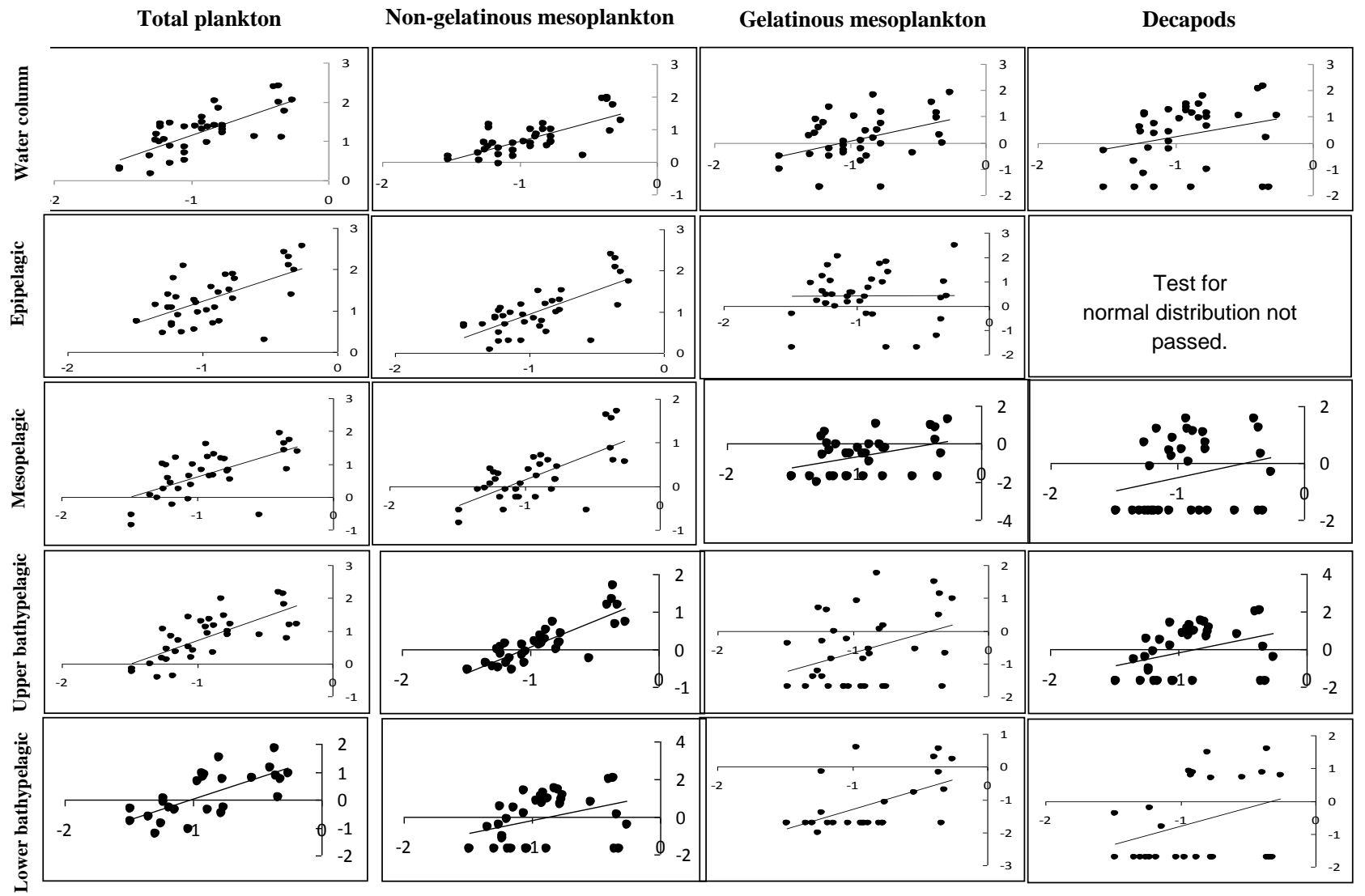

Figure 5. Wet biomass of major plankton groups (vertical axes) in the whole water column $\left(\mathrm{g} \mathrm{m}^{-2}\right)$ and in different vertical zones (mg $\mathrm{m}^{-3}$ ) versus surface chlorophyll (horizontal axes, $\mathrm{mg} \mathrm{m}^{-2}$ ).

conversion factors can be obtained to link geographically distant deep-sea assemblages.
- Actual wet biomass of gelatinous mesozooplankton is underestimated by our gear. A significant part of ctenophores and medusae are destroyed in the mesh during retrieval. Fragile gelatinous animals may dominate 


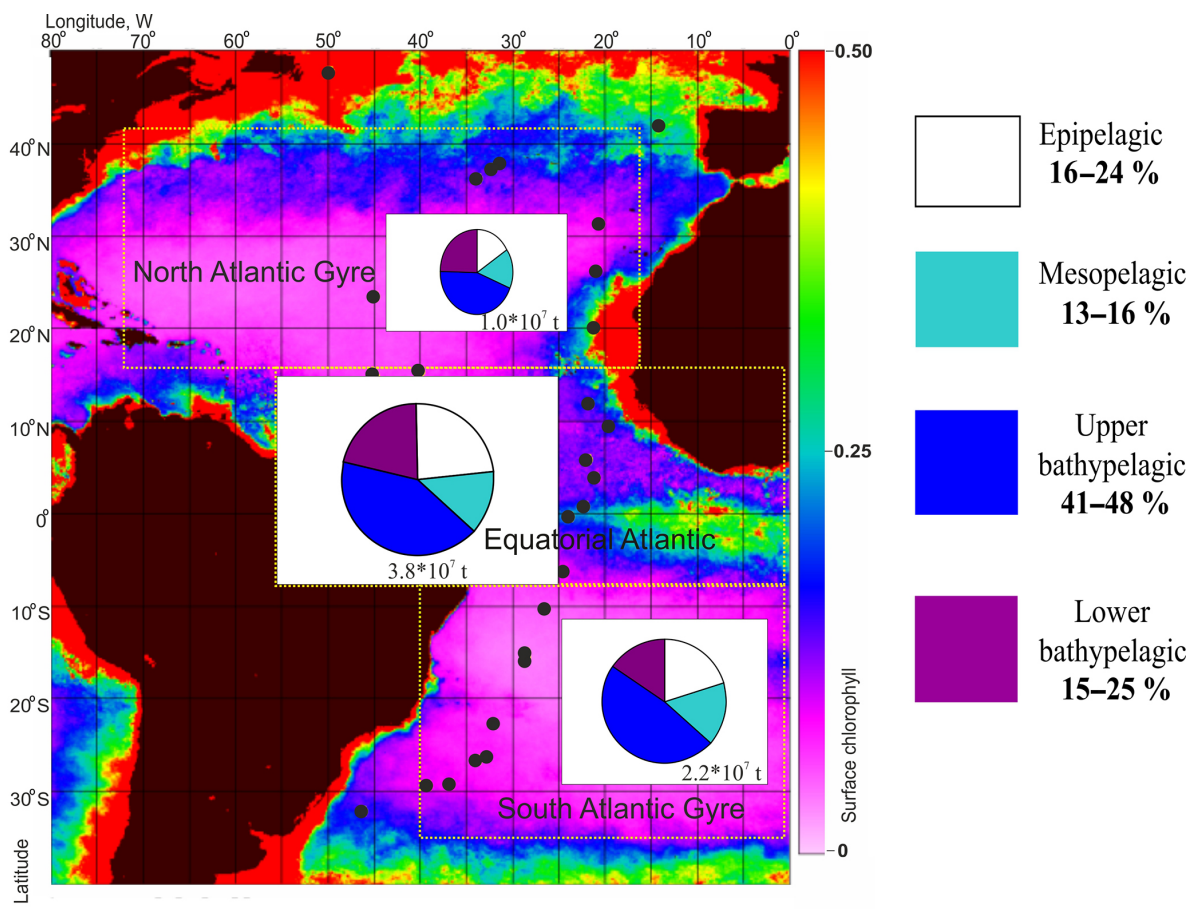

Figure 6. The standing stock (wet biomass) of the deep-sea plankton and contribution (\%) of vertical zones in the North, equatorial, and South Atlantic. Background: surface chlorophyll $a$ concentration averaged over 2013; scale $\left(\mathrm{mg} \mathrm{m}^{-2}\right)$ given on the right. Black circles: stations.

in the deep sea (Robison et al., 2010) and plankton nets are suboptimal for estimating their actual abundance (Vereshchaka and Vinogradov, 1999).

- Actual wet biomass of the decapods is also underestimated, as these animals likely avoid plankton nets and trawls to some extent (Vereshchaka, 1990).

Probably the most striking result we found was the unexpectedly high decapod wet biomass. Macroplanktonic decapod biomass, even in the maximum layers, is typically $0.05-0.5 \mathrm{mg} \mathrm{m}^{-3}$ and never exceeds $1.0 \mathrm{mg} \mathrm{m}^{-3}$ in the Atlantic (Foxton, 1970a, b), Indian (Vereshchaka, 1994), and southeastern Pacific oceans (Vereshchaka, 1990). The values presented are 1 order of magnitude higher (Table 1), which seems paradoxical, as the nets were smaller and should have ostensibly caught fewer and smaller decapods. Our observations from submersibles show that deep-sea decapods are generally stationary in the water column with abdomens oriented slightly upward. When disturbed, decapods try to escape and jump upward using the abdomen and tail fan. This behavior is effective in the pelagic realm, where predators are thought to attack from below, and thus many deep-pelagic decapods possess downward-oriented photophores for counterillumination (Widder, 1999). Upward jumps are also effective to escape from a net or a trawl that is traditionally towed in the horizontal direction. The BR net, however, is towed vertically and the decapods may have less chance to avoid the gear.
In contrast to decapods, pelagic fishes escape in the horizontal direction, as has been observed from submersibles many times by the authors. This reaction is successful when vertical hauls are used and our results are thus not representative for assessment of the pelagic fish biomass. This biomass may happen to be finally correlated with $\mathrm{Chl}$, but horizontally towed gears are necessary to prove that.

The dominance of macroplanktonic decapods in the deep sea illustrates an inverted biomass pyramid, as their biomass is larger than that of their prey (non-gelatinous mesozooplankton). This happens because decapods (typical life spans of several years) grow and reproduce much slower than mesozooplankton (typical life span several months), which equates to a low production rate relative to its high standing stock; ergo, the energy pyramid is not inverted. Thus, the decapod distribution offers additional example of the inverted biomass pyramid described for plankton communities (Gasol et al., 1997).

The most significant contribution to the total zooplankton standing stock unexpectedly came from the upper bathypelagic zone, not the epipelagic zone or the main thermocline (Fig. 6). The upper bathypelagic zone was dominated by macroplanktonic decapods, which accounted for over half of the standing stock wet biomass. Most decapods undertake diel vertical migration (Foxton, 1970a, b), feeding on mesozooplankton in the upper layers at night and hiding from predators in the dark upper bathypelagic zone by day. This 
behavior appears effective and provides good prospects for biomass accumulation below the main thermocline in the ocean. The finding of higher than expected biomass deep in the water column mirrors recent findings that suggest deeppelagic fish biomass has been underestimated by up to an order of magnitude (Kaartvedt et al., 2012; Irigoien et al., 2014). The global ramifications of these findings, coupled with ours, are that energy transfer efficiency from phytoplankton to intermediate and higher trophic levels in oceanic ecosystems has been underestimated, and that both zooplankton and fishes are likely respiring a large portion of the primary production in the deep-pelagic realm. Our results suggest that the contribution of the deep-ocean pelagic fauna for biogeochemical cycles maybe more important than previously thought.

\section{Data availability}

Data are available at https://www.researchgate.net/profile/A_ Vereshchaka/contributions.

Acknowledgements. The studies were supported by the Presidium Program 3P of the Russian Academy of Sciences. We also thank Dr. Alexander Mikaelyan for his help.

Edited by: G. Herndl

Reviewed by: A. Yamaguchi and one anonymous referee

\section{References}

Böttger-Schnack, R.: Vertical structure of small metazoan plankton, especially non-calanoid copepods, I. Deep Arabian Sea, J. Plankton Res., 18, 1073-1101, 1996.

Brodsky, K. A.: Calanoida of the Far East and the Polar Basin, Leningrad Academy of Science Public House, 342 pp., 1950 (in Russian).

Brodsky, K. A., Vyshkvartzeva, N. V., Kos, M. S., and Markhaseva, E. L.: Copepoda Calanoida of the seas of the USSR and adjastent seas, Opredeliteli po faune SSSR, 35, 1-358, 1983.

Burghart, S. E., Hopkins, T. L., and Torres J. J.: The bathypelagic Decapoda, Lophogastrida, and Mysida of the eastern Gulf of Mexico, Mar. Biol., 152, 315-327, 2007.

Cartes, J. E., Fanelli, E., Papiol, V., and Maynou, F. Trophic relationships at intrannual spatial and temporal scales of macro and megafauna around a submarine canyon off the Catalonian coast (western Mediterranean), J. Sea Res., 63, 180-190, 2010.

de Melo, T. X., Lourenço, L. D. J. S., and Medeiros, E. S. F.: Checklist of zooplankton from the upper Ipanema River (Pernambuco), an intermittent river in semi-arid Brazil, Check List, 10, 524528, 2014.

di Carlo, B. S., Ianora, A., Fresi, E., and Hure, J. Vertical zonation patterns for Mediterranean copepods from the surface to $3000 \mathrm{~m}$ at a fixed station in the Tyrrhenian Sea, J. Plankton Res., 6, 10311056, 1984.
Dawson, M. N.: Species richness, habitable volume, and species densities in freshwater, the sea, and on land, Front. Biogeogr., 4 , 105-116, 2012.

Foxton, P.: The Vertical Distribution of Pelagic Decapods [Crustacea: Natantia] Collected on the Sond Cruise 1965, I. The Caridea, J. Mar. Biol. Ass. UK, 50, 939-960, 1970a.

Foxton, P.: The Vertical Distribution of Pelagic Decapods [Crustacea: Natantia] Collected on the Sond Cruise 1965, II. The Penaeidea and General Discussion, J. Mar. Biol. Ass. UK, 50, 9611000, 1970b.

Gaard, E., Gislason, A., Falkenhaug, T., Søiland, H., Musaeva, E., Vereshchaka, A., and Vinogradov, G.: Horizontal and vertical copepod distribution and abundance on the Mid-Atlantic Ridge in June 2004, Deep-Sea Res. Pt. II, 55, 59-71, 2008.

Gasol J. M., del Giorgio, P. A., and Duarte C. M.: Biomass distribution in marine planktonic communities, Limnol. Oceanogr., 42, 1353-1363, 1997.

Gislason, A.: Life-cycle strategies and seasonal migrations of oceanic copepods in the Irminger Sea, Hydrobiologia, 503, 195209, 2003.

Gregg, W. W. and Rousseaux, C. S.: Decadal trends in global pelagic ocean chlorophyll: A new assessment integrating multiple satellites, in situ data, and models, J. Geophys. Res.-Oceans, 119, 5921-5933, 2014.

Hammer, Ø., Harper, D. A. T., and Ryan, P. D. PAST: Paleontological Statistics Software Package for education and data analysis, Palaeontolia Electronica, 2001.

Irigoien, X., Klevjer, T. A., Røstad, A., Martinez, U., Boyra, G., Acuña, J. L., Bode, A., Echevarria, F., Gonzalez-Gordillo, J. I., Hernandez-Leon, S., Agusti, S., Aksnes, D. L., Duarte, C. M., and Kaartvedt, S.: Large mesopelagic fishes biomass and trophic efficiency in the open ocean, Nat. Commun., 5, 3271, doi:10.1038/ncomms4271, 2014.

Kaartvedt, S., Staby, D., and Aksnes, D.: Efficient trawl avoidance by mesopelagic fishes causes large underestimation of their biomass, Mar. Ecol. Progr. Ser., 456, 1-6, 2012.

Koppelmann, R. and Weikert, H.: Full-depth zooplankton profiles over the deep bathyal of the NE Atlantic, Mar. Ecol.-Prog. Ser., 82, 263-272, 1992.

Koppelmann, R. and Weikert, H.: Deep Arabian Sea mesozooplankton distribution, Intermonsoon, October 1995, Mar. Biol., 129, 549-560, 1997.

Koppelmann, R. and Weikert, H.: Temporal changes of deep-sea mesozooplankton abundance in the temperate NE Atlantic and estimates of the carbon budget, Mar. Ecol.-Prog. Ser., 179, 2740, 1999.

Lindsay, D. J. and Hunt J. C.: Biodiversity in midwater cnidarians and ctenophores: submersible-based results from deep-water bays in the Japan Sea and northwestern Pacific, J. Mar. Biol. Ass. UK, 85, 503-517, 2005.

Longhurst, A. and Williams, R.: Materials for plankton modelling: vertical distribution of Atlantic zooplankton in summer, J. Plankton Res., 1, 1-28, 1979.

Markhasheva, E. L.: Calanoid copepods of the family Aedideidae of the World Ocean, in: Proceedings of the Zoological Institute in St. Petersburg, St. Petersburg, 331 pp. 1996.

Mauchline, J. and Fisher, L. R.: The Biology of Euphausiids, Adv. Mar. Biol., 1-454, 1969. 
Murano, M., Marumo, R., Nemoto, T., and Aizawa, Y.: Vertical distribution of biomass of plankton and micronekton in the Kuroshio Water off central Japan, Bulletin of Plankton Society of Japan 23, 1-12, 1976.

Okey, T. A., Alidina, H. M., Lo, V., Montenegro, A., and Jessen, S.: Climate change impacts and vulnerabilities in Canada's Pacific marine ecosystems, World Wildlife Fund/Canadian Parks and Wilderness Society, Vancouver, Vancouver, 157 pp., 2012.

Robison, B. H., Sherlock, R. E., and Reisenbichler, K.: The bathypelagic community of Monterey Canyon, Deep-Sea Res. Pt. II, 57, 1551-1556, 2010.

Rose, M.: Faune de France, 26. Copepods Pelagiques, Typographie Firmin-Didot et cie, Paris, 374 pp., 1933.

Sameoto, D. D.: Influence of the biological and physical environment on the vertical distribution of mesozooplankton and micronekton in the eastern tropical Pacific, Mar. Biol., 93, 263-279, 1986.

Smith, K. L., Baldwin, R. J., Karl, D. M., and Boetius, A.: Benthic community responses to pulses in pelagic food supply: North $\mathrm{Pa}-$ cific Subtropical Gyre, Deep-Sea Res Pt. I, 49, 971-990, 2002.

Ter Braak, C. J.: Canonical correspondence analysis: a new eigenvector technique for multivariate direct gradient analysis, Ecology, 67, 1167-1179, 1986.

Ter Braak, C. J. and Verdonschot, P. F.: Canonical correspondence analysis and related multivariate methods in aquatic ecology, Aquat. Sci., 57, 255-289, 1995.

Uitz, J., Claustre, H., Morel, A., and Hooker, S. B.: Vertical distribution of phytoplankton communities in open ocean: An assessment based on surface chlorophyll, J. Geophys. Res., 111, C08005, doi:10.1029/2005JC003207, 2006.

Vereshchaka, A., Abyzova, G., Lunina, A., and Musaeva, E.: The deep-sea zooplankton of the North, Central, and South Atlantic: Biomass, abundance, diversity, Deep-Sea Res. Pt. II, doi:10.1016/j.dsr2.2016.06.017i, 2016.

Vereshchaka, A. L.: Pelagic decapods from seamounts of the Nazca and Sala-y-Gomez ridges, Plankton and benthos from the Nazca and Sala-y-Gomez submarine ridges, Trud. Inst. Okeanol, Acad. Sci., Moscow, 124, 129-155, 1990a.

Vereshchaka, A. L.: Distribution of euphausiids over seamounts of Nazca and Sala-y-Homez ridges, Plankton and benthos from the Nazca and Sala-y-Gomez submarine ridges, Trud. Inst. Okeanol, Acad. Sci., Moscow, 124, 112-117, 1990b.

Vereshchaka, A. L.: Macroplankton in the near-bottom layer of the continental slopes and seamounts, Deep-Sea Res. Pt. I, 42, 16391668, 1995.

Vereshchaka, A. L. and Vinogradov, G. M.: Visual observations of vertical distribution of plankton through the water column above Broken Spur vent field, Mid-Atlantic Ridge, Deep-Sea Res. Pt. I, 46, 1615-1632, 1999.
Vinogradov, G. M.: Vertical distribution of macroplankton at the Charlie-Gibbs Fracture Zone (North Atlantic), as observed from the manned submersible "Mir-1", Mar. Biol., 146, 325-416, 2005.

Vinogradov, M. E.: Vertical Distribution of the Oceanic Zooplankton. Institute of Oceanography Academy Science USSR, Moscow, 339 pp., (English translation, I.P.S.T., 419 Jerusalem, 1970), 1968.

Vinogradov, M. E. and Shushkina, E. A.: Functioning of the Plankton Communities in the Oceanic Epipelagial, Moscow, Nauka, 1987.

Vinogradov, M. E., Vereshchaka, A, L., and Shushkina, E. A.: Vertical structure of the zooplankton communities in the oligotrophic areas of the Northern Atlantic, and influence of the hydrothermal vent, Okeanologiya, 36, 71-79, 1996.

Vinogradov, M. E., Shushkina, E. A., Nezlin, N. P., Vedernikov, V. I., and Gagarin, V. I.: Correlation between different parameters of the ecosystem of the epipelagic zone of the World Ocean, Oceanology, 39, 54-63, 1999.

Vinogradov, M. E., Vereshchaka, A. L., and Vinogradov, G. M.: Vertical distribution of zooplankton at the periphery of the North Atlantic subtropical gyre, Izvestiya Akademii Nauk Seriya Biologicheskaya, 4, 496-510, 2000.

Weikert, H. and Trinkaus, S.: Vertical mesozooplankton abundance and distribution in the deep Eastern Mediterranean Sea SE of Crete, J. Plankton Res., 12, 601-628, 1990.

Widder, E. A.: Bioluminescence, in: Adaptive Mechanisms in the Ecology of Vision, Springer Netherlands, 555-581, 1999.

Yamaguchi, A., Watanabe, Y., Ishida, H., Harimoto, T., Furusawa, K., Suzuki, S., Ishizaka, J., Ikeda, T., and Takahashi, M. M.: Community and trophic structures of pelagic copepods down to greater depths in the western subarctic Pacific (WESTCOSMIC), Deep-Sea Res. Pt. I, 49, 1007-1025, 2002a.

Yamaguchi, A., Watanabe, Y., Ishida, H., Harimoto, T., Furusawa, K., Suzuki, S., Ishizaka, J., Ikeda, T., and Takahashi, M. M. Structure and size distribution of plankton communities down to the greater depths in the western North Pacific Ocean, Deep-Sea Res. Pt. II, 49, 5513-5529, 2002 b.

Yamaguchi, A., Watanabe, Y., Ishida, H., Harimoto, T., Furusawa, K., Suzuki, S., Ishizaka, J., Ikeda, T., and Takahashi, M. M.: Latitudinal differences in the planktonic biomass and community structure down to the greater depths in the western North Pacific, J. Oceanogr., 60, 773-787, 2004. 